\title{
Erratum to: Pancreatic cancer cell-derived IGFBP-3 contributes to muscle wasting
}

Xiu-yan Huang ${ }^{1 * \dagger}$, Zi-li Huang ${ }^{2 \dagger}$, Ju-hong Yang ${ }^{3 \dagger}$, Yong-hua X ${ }^{2}$, Jiu-Song Sun ${ }^{4,5}$, Qi Zheng ${ }^{1}$, Chunyao Wei ${ }^{6}$, Wei Song ${ }^{7}$ and Zhou Yuan ${ }^{1 *}$

Unfortunately, in the PDF of the original version of this article [1] there was an error. The names of two of the co-first authors were included incorrectly in the footnote and read "Xiu-yang Huang" and "Juhong Yang "instead of "Xiu-yan Huang" and "Ju-hong Yang". The sentence should have read "Xiu-yan Huang, Zi-li Huang, and Juhong Yang are co-first authors".

The names have been also updated in the original article.

\section{Author details \\ 'Department of General Surgery, Shanghai Jiaotong University Affiliated Sixth People's Hospital, Shanghai 200233, P.R China. ²Department of Radiology, Xuhui Central Hospital, Shanghai 200031, P.R China. ${ }^{3}$ Collaborative Innovation Center of Tianjin for Medical Epigenetics, Key Laboratory of Hormone and Development (Ministry of Health), Metabolic Disease Hospital \& Tianjin Institute of Endocrinology, Tianjin Medical University, Tianjin 300070, China. ${ }^{4}$ Department of Cancer Immunology and AIDS, Dana-Farber Cancer Institute, 450 Brookline Ave, Boston, MA 02215, USA. ${ }^{5}$ Department of Medicine, Harvard Medical School, 25 Shattuck Street, Boston, MA 02115, USA. ${ }^{6}$ Department of Molecular Biology, Howard Hughes Medical Institute, Massachusetts General Hospital, Boston, MA, USA. 'Department of Genetics, Harvard Medical School, Boston, MA 02115, USA.}

Received: 7 April 2016 Accepted: 7 April 2016

Published online: 10 May 2016

\section{Reference}

1. Huang $X Y$, Huang $Z L$, Yang $J H, X u Y H$, Sun JS, Zheng $Q$, et al. Pancreatic cancer cell-derived IGFBP-3 contributes to muscle wasting. J Exp Clin Cancer Res. 2016;35(1):46. doi:10.1186/s13046-016-0317-z.

\footnotetext{
*Correspondence: xyhuang1119@163.com; zhouyuan201414@163.com ${ }^{\dagger}$ Equal contributors

'Department of General Surgery, Shanghai Jiaotong University Affiliated Sixth People's Hospital, Shanghai 200233, P.R China
}

Submit your next manuscript to BioMed Central and we will help you at every step:

- We accept pre-submission inquiries

- Our selector tool helps you to find the most relevant journal

- We provide round the clock customer support

- Convenient online submission

- Thorough peer review

- Inclusion in PubMed and all major indexing services

- Maximum visibility for your research

Submit your manuscript at www.biomedcentral.com/submit

\section{() Biomed Central}

